\title{
Health status and related factors in farmers by SF-12
}

Kyungeun Park', Sooyong Roh', Jihoon Lee ${ }^{1}$, Soon Chan Kwon', Mihye Jeong ${ }^{2}$ and Soo-jin Lee ${ }^{1 *}$

\begin{abstract}
Objectives: This study was performed to understand farmers' health status by general characteristic, and to find out the related factors.

Methods: All the 984 subjects were interviewed by means of a structured questionnaire and SF-12. Among them, only 812 were eligible for analysis. Statistical methods used included frequency, t-test, ANOVA, binary logistic regression with SPSS 19.0.

Results: In binary logistic regression, marital status, smoking, regular exercise and monthly day off were associated with physical component score. Marital status, smoking and score of pesticide protective device wearing were associated with mental component score.

Conclusions: This study suggests that effort to develop health promotion programs for workers of agricultural industry considering these results can improve their perceived health status.
\end{abstract}

Keywords: Farmer, Health status

\section{Introduction}

Since the 1960s, an economic policy changed Korea from agricultural to industrial society. This economic structural change immensely affected the farmlands resulting in the exodus of young adults from rural to city becoming worse over time. It made rural areas to become an aging society. In other words, continuous shortage of labor of younger age group caused increasing labor intensity among elderly and women which are major issues today. The method of agriculture is changing from farming crops of rice in summer and barley in winter to utilizing facility horticulture like green house. But many farmers still work in a classical method of small scale intensive labor [1,2].

There are some disadvantages with respect to provision of medical care in a rural society. Excessive physical labor, increasing number of female farmers, low socioeconomic status due to lack of education, poor sanitation environment, intensive labor industry and lack of concern about health are disadvantages. Thus, farmers have difficulty utilizing health related facilities. Besides, they must endure outdoor and household work themselves even at their

\footnotetext{
* Correspondence: sjlee@hanyang.ac.kr

'Department of Occupational and Environmental Medicine, Hanyang University, Seoul, South Korea

Full list of author information is available at the end of the article
}

advancing years due to lack of manpower. As a result, farmers' physical and mental function tend to deteriorate rapidly $[3,4]$.

Although agriculture plays a major role in the food production industry, farming population decreased from $10,830,000$ in 1980 to $3,060,000$ in 2010. But it still comprises $6.3 \%$ of the nation's population $(48,580,000)$ which is one of the reason why farmers' health care is important [5].

A national approach is necessary to solve farmers' health care problem because it could affect national food supply. A planned health promotion program is needed before they are affected with a disease. In other words, farmers' health promotion planning and action may maximize their health potential which can extend life and reduce health care cost. It can solve individual's basic health needs and increase productivity in the agricultural industry as a result [6].

Developing and distribution of standardized program is needed for effective farmers' health promotion. Understanding of farmers' health status and related factors must precede the purpose.

There are various tools to evaluate self-health awareness. SF-36 which Ware et al developed is verified on 
reliability and validity among others. It was used on previous workers' health status evaluations several times [7-11]. SF-12 which has 12 physical and psychological questions is a simpler tool of SF-36 for convenient use. Because 36 questions are too many to answer by elderly farmers, question response rate and accuracy may not be good. Therefore, SF-12 was utilized $[12,13]$.

This study was conducted to evaluate farmers' health status and related factors in order to develop farmers' health promotion program.

\section{Materials and methods \\ Subjects}

Farmers who live in farm work safety model demonstration town were the subjects of this study. In nine provinces, 18 town 984 people agreed to and joined this study. We carried out a survey using questionnaires. The final subjects were 812 people after excluding inappropriate questionnaires.

\section{Survey tool}

The questionnaire was composed of sociodemographic factors, life habit factors, occupational characteristics, and subjective health status (SF-12). Occupational characteristics were composed of pesticide exposure (total, annual, and daily), annual labor period, daily labor period, and monthly leave. Total pesticide exposure was divided into 3 groups, other variables were divided into 2 groups. The scores of pesticide protective device wearing and the pesticide exposure rule observance were divided into 2 groups by median value.

Subjective health status evaluation was done using SF12. This tool has 12 questions composed of physical and mental components. The physical component is subdivided into physical functioning, role physical, bodily pain, and general health. The mental component is subdivided into mental health, role emotional, social functioning, and vitality. Each question was considered a 100 point. High score meant good health status.

\section{Analytical method}

Collected material was analyzed by SPSS 19.0. Analysis of the frequency was used for the general characteristics of the subjects. In order to know the health status of the general characteristics, we conducted t-test and analysis of variance (ANOVA). We conducted binary logistic regression to control variables which can affect SF-12 score.

\section{Results}

\section{General characteristics of subjects}

Of the 812 research subjects (397 men and 415 women), the average score was 61.4, with 233 subjects $(28.7 \%)$ aged between 70-79 years. Among the total, 657 (80.9\%)
Table 1 General characteristics of subjects $(N=812)$

\begin{tabular}{llll}
\hline Variables & & Number & $\%$ \\
\hline Gender & Male & 397 & 48.9 \\
Age(years) & Female & 415 & 51.1 \\
& $\leq 49$ & 137 & 16.9 \\
& $50-59$ & 211 & 26.0 \\
& $60-69$ & 205 & 25.2 \\
& $70-79$ & 233 & 28.7 \\
Marital status & $\geq 80$ & 26 & 3.2 \\
& Single & 217 & 19.1 \\
Smoking* & Married & 657 & 80.9 \\
& NO & 557 & 68.6 \\
Alcohol* & Yes & 227 & 28.0 \\
& NO & 453 & 55.8 \\
Regular exercise* & Yes & 344 & 42.4 \\
& NO & 436 & 53.7 \\
& Yes & 372 & 45.8 \\
\hline
\end{tabular}

*excluded no-response.

subjects reported having a spouse at the time. In addition 227 (28.0\%) subjects were smokers, 344 (42.4\%) subjects were alcohol consumers, and $372(45.8 \%)$ subjects exercised regularly (Table 1 ).

\section{Health status (SF-12) of subjects}

The average score of SF-12 was $52.66 \pm 14.03$. The physical component score was $52.97 \pm 15.61$. Physical functioning was $63.76 \pm 35.17$, role physical was $61.44 \pm 31.99$, bodily pain was $28.17 \pm 11.00$, and general health was $67.46 \pm 10.52$. The mental component score was $52.35 \pm$ 17.19. Mental health was $72.49 \pm 24.81$, role emotional was $76.83 \pm 20.00$, social functioning was $18.78 \pm 3.18$, and vitality was $39.99 \pm 15.04$ (Table 2 ).

Table 2 Health status(SF-12) of subjects ( $\mathrm{N}=\mathbf{8 1 2}$ )

\begin{tabular}{ccc}
\hline Scale & Mean \pm SD \\
\hline SF-12 & $52.66 \pm 14.03$ \\
& Physical component score & $52.97 \pm 15.61$ \\
& PF(Physical functioning) & $63.76 \pm 35.17$ \\
RP(Role physical) & $61.44 \pm 31.99$ \\
BP(Bodily pain) & $28.14 \pm 11.00$ \\
GH(General health) & $57.46 \pm 10.52$ \\
Mental component score & $52.35 \pm 17.19$ \\
MH(Mental health) & $72.49 \pm 24.81$ \\
RF(Role emotional) & $76.83 \pm 20.00$ \\
SF(Social functioning) & $18.78 \pm 3.18$ \\
VT(Vitality) & $39.99 \pm 15.04$ \\
\hline
\end{tabular}


The health status by general characteristics

Table 3 shows health status by general characteristics. The women's mental component score was $51.08 \pm 16.77$ and the mens' score was $53.68 \pm 17.55$. The physical component score of the subjects who had a spouse was $54.04 \pm 15.32$, and the mental component score was $53.11 \pm 17.11$. The physical component score of the subjects who did not have a spouse was $48.42 \pm 16.06$, and the mental component score was $49.11 \pm 17.23$. The smoker's physical component score was $57.38 \pm 14.34$ and the mental component score was $55.13 \pm 17.52$. The drinker's physical component score was 56.04 \pm 14.30 and the mental component score was $54.13 \pm 16.06$. The non-drinker's physical component score was $50.51 \pm$ 16.19 and the mental component score was $50.68 \pm$ 17.55. The regular exercise group's physical component score was $54.40 \pm 15.56$ which was higher than the nonexercise group's score $(51.67 \pm 15.61)$. The regular exercise group's mental component score was $53.53 \pm 16.28$ and the non-exercise group was $51.12 \pm 17.74$. The physical component score depended on the total pesticide exposure period. Post-hoc comparison result, less than 20 years

Table 3 The health status by general characteristics $(\mathrm{N}=\mathbf{8 1 2})$

\begin{tabular}{|c|c|c|c|c|c|}
\hline \multirow[t]{2}{*}{ Variables } & & \multicolumn{2}{|c|}{ Physical component score } & \multicolumn{2}{|c|}{ Mental component score } \\
\hline & & Mean \pm SD & p value $^{\dagger}$ & Mean \pm SD & p value ${ }^{\dagger}$ \\
\hline \multirow[t]{2}{*}{ Gender } & Male & $52.50 \pm 15.82$ & 0.403 & $53.68 \pm 17.55$ & 0.031 \\
\hline & Female & $53.41 \pm 15.42$ & & $51.08 \pm 16.77$ & \\
\hline \multirow[t]{5}{*}{ Age(years) } & $\leq 49$ & $53.78 \pm 15.62$ & 0.064 & $53.13 \pm 18.21$ & 0.523 \\
\hline & $50-59$ & $52.71 \pm 15.56$ & & $52.16 \pm 16.83$ & \\
\hline & $60-69$ & $53.95 \pm 15.14$ & & $52.27 \pm 17.79$ & \\
\hline & $70-79$ & $50.93 \pm 15.94$ & & $51.54 \pm 16.64$ & \\
\hline & $\geq 80$ & $61.20 \pm 14.11$ & & $57.57 \pm 14.69$ & \\
\hline \multirow[t]{2}{*}{ Marital status } & Single & $48.42 \pm 16.06$ & $<0.001$ & $49.11 \pm 17.23$ & 0.009 \\
\hline & Married & $54.04 \pm 15.32$ & & $53.11 \pm 17.11$ & \\
\hline \multirow[t]{2}{*}{ Smoking $^{\ddagger}$} & NO & $51.14 \pm 15.76$ & $<0.001$ & $50.83 \pm 16.75$ & 0.001 \\
\hline & Yes & $57.38 \pm 14.34$ & & $55.13 \pm 17.52$ & \\
\hline \multirow[t]{2}{*}{ Alcohol $^{\ddagger}$} & NO & $50.51 \pm 16.19$ & $<0.001$ & $50.68 \pm 17.55$ & 0.004 \\
\hline & Yes & $56.04 \pm 14.30$ & & $54.13 \pm 16.06$ & \\
\hline \multirow[t]{2}{*}{ Regular exercise ${ }^{\ddagger}$} & NO & $51.67 \pm 15.61$ & 0.013 & $51.12 \pm 17.74$ & 0.046 \\
\hline & Yes & $54.40 \pm 15.56$ & & $53.53 \pm 16.28$ & \\
\hline \multirow[t]{3}{*}{ Total pesticide exposure(years) ${ }^{\ddagger}$} & $\leq 20$ & $55.41 \pm 14.53$ & 0.016 & $54.00 \pm 15.55$ & 0.067 \\
\hline & $21-36$ & $53.32 \pm 14.48$ & & $52.94 \pm 16.16$ & \\
\hline & $>36$ & $51.48 \pm 15.79$ & & $50.54 \pm 17.95$ & \\
\hline \multirow[t]{2}{*}{ Annual pesticide exposure(days) ${ }^{\ddagger}$} & $\leq 14$ & $53.91 \pm 15.44$ & 0.602 & $53.23 \pm 15.54$ & 0.340 \\
\hline & $>14$ & $53.31 \pm 14.89$ & & $52.02 \pm 17.57$ & \\
\hline \multirow[t]{2}{*}{ Daily pesticide exposure(hours) $^{\ddagger}$} & $\leq 2$ & $52.39 \pm 14.91$ & 0.058 & $51.29 \pm 16.75$ & 0.070 \\
\hline & $>2$ & $54.59 \pm 15.23$ & & $53.60 \pm 16.46$ & \\
\hline \multirow[t]{2}{*}{ Annual labor period (months) ${ }^{\ddagger}$} & $\leq 9$ & $52.85 \pm 15.81$ & 0.141 & $51.84 \pm 16.95$ & 0.112 \\
\hline & $>9$ & $54.48 \pm 14.75$ & & $53.76 \pm 16.33$ & \\
\hline \multirow[t]{2}{*}{ Daily labor period (hours) } & $\leq 8$ & $54.44 \pm 15.15$ & 0.005 & $52.75 \pm 17.28$ & 0.483 \\
\hline & $>8$ & $51.34 \pm 15.93$ & & $51.90 \pm 17.11$ & \\
\hline \multirow[t]{2}{*}{ Monthly day off(days) ${ }^{\ddagger}$} & $\leq 4$ & $52.06 \pm 15.23$ & 0.012 & $52.63 \pm 16.42$ & 0.736 \\
\hline & $>4$ & $54.91 \pm 15.46$ & & $52.21 \pm 16.71$ & \\
\hline \multirow[t]{2}{*}{ Score of pesticide protective device wearing } & $\leq 15$ & $51.54 \pm 16.17$ & 0.010 & $50.01 \pm 17.43$ & $<0.001$ \\
\hline & $>15$ & $54.36 \pm 14.94$ & & $54.64 \pm 16.66$ & \\
\hline \multirow[t]{2}{*}{ Score of pesticide exposure rule observance } & $\leq 20$ & $52.66 \pm 15.59$ & 0.568 & $51.89 \pm 17.17$ & 0.444 \\
\hline & $>20$ & $53.28 \pm 15.65$ & & $52.81 \pm 17.23$ & \\
\hline
\end{tabular}

${ }^{\dagger} \mathrm{p}$ value by t-test or ANOVA.

${ }^{\ddagger}$ excluded no-response. 
exposure group and more than 36 years exposure group showed a significant difference. Less than 8 hours labor group showed a higher physical component score than exceeding 8 hours labor group. Less than 4 days monthly day off group represented a higher physical component score than exceeding 4 days monthly day off group. The group of good protective device wearing received more scores in both components significantly. Age, annual pesticide exposure, daily pesticide exposure, annual labor period and score of pesticide exposure rule observance did not make any significant difference.

\section{Factors related with health status}

The physical and the mental component scores of SF-12 were divided into 2 groups. One was the high score group and the other was the low score group by median value. Binary logistic regression analysis was done with dependent variables which showed significant difference in univariate analysis.

On the physical component score, the odds ratio of the subjects who had a spouse was $1.89(95 \% \mathrm{CI}=1.21$ $2.95)$, The smoker group's odds ratio was $2.24(95 \% \mathrm{CI}=$ 1.56-3.21), the regular exercise group's odds ratio was 1.37 ( $95 \% \mathrm{CI}=1.01-1.86)$, and more than 4 days monthly day off group's odds ratio was $1.54(95 \% \mathrm{CI}=1.11-2.14)$ (Table 4).

On the mental component score, the odds ratio of the subjects who had a spouse was $1.64(95 \% \mathrm{CI}=1.12$ $2.42)$, The smoker group's odds ratio was $1.57(95 \% \mathrm{CI}=$ 1.14-2.16), The odds ratio of the high score group of

Table 4 Factors related with physical component score by binary logistic regression analysis

\begin{tabular}{|c|c|c|c|}
\hline Variables & & Adjusted OR & $95 \%$ C.I. \\
\hline \multirow[t]{2}{*}{ Marital status } & Single & 1.00 & \\
\hline & Married & 1.89 & $1.21-2.95$ \\
\hline \multirow[t]{2}{*}{ Smoking } & No & 1.00 & \\
\hline & Yes & 2.24 & $1.56-3.21$ \\
\hline \multirow[t]{2}{*}{ Alcohol } & No & 1.00 & \\
\hline & Yes & 1.37 & $0.99-1.89$ \\
\hline \multirow[t]{2}{*}{ Regular exercise } & No & 1.00 & \\
\hline & Yes & 1.37 & $1.01-1.86$ \\
\hline \multirow[t]{3}{*}{ Total pesticide exposure(years) } & $\leq 20$ & 1.00 & \\
\hline & $21-36$ & 1.01 & $0.65-1.51$ \\
\hline & $\geq 37$ & 0.75 & $0.51-1.11$ \\
\hline \multirow[t]{2}{*}{ Daily labor period (hours) } & $\leq 8$ & 1.00 & \\
\hline & $>8$ & 0.92 & $0.66-1.29$ \\
\hline \multirow[t]{2}{*}{ Monthly day off(days) } & $\leq 4$ & 1.00 & \\
\hline & $\geq 5$ & 1.54 & $1.11-2.14$ \\
\hline \multirow{2}{*}{$\begin{array}{l}\text { Score of pesticide protective } \\
\text { device wearing }\end{array}$} & $\leq 15$ & 1.00 & \\
\hline & $\geq 16$ & 1.19 & $0.85-1.67$ \\
\hline
\end{tabular}

pesticide protective device wearing was $1.57(95 \% \mathrm{CI}=$ 1.17-2.10) (Table 5).

\section{Discussion}

Korea's agriculture plays a major role in the food production industry and concern for farmer's health is increasing. Especially, farmers tend to be more elderly compared to any other industry. Understanding farmers' health status is basically an important step. In this study, marriage status, smoking, regular exercise, monthly day off and pesticide protective device wearing were significant variables in farmers' health status.

SF-12 score of the subjects was 52.66 out of 100 . The study of Cha BS et al (1998) which showed the assessment of workers' health status by SF-36 showed 69.61, manufacturer male employees' assessment by SF-36 (Kim SA et al, 2006) was 78.44, and Lee SM (2010)'s study of large workplace employees in Daejeoun and Chungchung health status assessment by SF-12 showed $75.75[11,14,15]$. All of the above studies showed higher scores than this study. It may be because the farmers were older or there were more number of females or had less education or lower economic level than in the other workplace. In Jun JY's study which evaluated elderly in a rural area by SF-36 revealed 56.15. It was higher than this study. Such study included subjects who were all elderly in an area regardless of farming. But it was difficult to compare because the number of subjects was too small [16].

On the mental component score, the females' score was lower than the males'. It corresponded with previous studies which showed that the females generally had a lower health status than males [12,15,17-19]. There are some points to be considered. Nettleton (1995) explained that women work double hours at home and at work which causes negative effect on health. On the other hand, MacIntyre (1993) said that women tend to

Table 5 Factors related with mental component score by binary logistic regression analysis

\begin{tabular}{llll}
\hline Variables & & Adjusted OR & 95\% C.I. \\
\hline Gender & Male & 1.00 & \\
& Female & 0.85 & $0.64-1.14$ \\
Marital status & Single & 1.00 & \\
& Married & 1.64 & $1.12-2.42$ \\
Smoking & No & 1.00 & \\
& Yes & 1.57 & $1.14-2.16$ \\
Alcohol & No & 1.00 & $0.93-1.72$ \\
& Yes & 1.26 & \\
Regular exercise & No & 1.00 & $0.87-1.57$ \\
& Yes & 1.17 & $1.17-2.10$ \\
Score of pesticide & $\leq 15$ & 1.00 & \\
protective device wearing & $\geq 16$ & 1.57 &
\end{tabular}


know more about their health status, and men exaggerate their health $[20,21]$.

This study did not show significant difference in health status according to age. It does not follow previous studies which explains that health status decreases with age $[12,17,18,22-24]$. But some studies in elderly subjects showed that health status does not have correlation with age [25]. And the average age of the subjects was 64.1 which was high and many of them were more than their 60 's in this study. Therefore, it may not appropriate to compare.

Health status in married group was higher than in single group. Previous studies showed similar results. Existing spouse is helpful in physical health management and psychological stability $[14,16,26,27]$.

Smokers' health status score was higher than nonsmokers' score. It was similar to previous studies $[28,29]$. However, there are many reports which explain that smoking has negative health effect and stop smoking in old age is helpful in improvement of health and quality of life [30]. And smoking can be a confounding factor. Alcohol did not have any significant correlation. The regular exercise group had a higher health status score. It corresponded with other studies [28,31,32].

Pesticide exposure did not show any significant relation. Long time pesticide exposure group tended to have low scores, but was not significant after revision. Meanwhile pesticide protective device wearing had a positive effect, especially the mental component. People who made efforts to wear protective device tended to have more concern about health. It was meaningful that there were few previous studies concerning the association of protective device and health. Longer monthly day off group had higher physical component scores. There were some similar results about the association between working day and health [33-35].

There are some limitations in this study. First of all, this study was carried out targeting 9 provinces in the country, but the sampling count per each town was too small. Therefore, it cannot be generalized among all farmers. And there were many differences in working conditions by crop. A close investigation was needed further. Secondly, this study was a cross-sectional research. The association of variables was found to exist, but the order of time was not clear. Lastly, there were omitted variable bias. The subjects were old age, but a questionnaire was used. BMI, income level, education level and sleeping hours which are related to health were omitted $[25,36]$.

\section{Conclusion}

Farmers had disadvantages in medical approach. Developing a program is needed to manage them. According to this study, life style improvement, education of pesticide use like protective device wearing and proper working time and rest have to be considered.

Further research on the subjects after application of the improvement program based on this study is necessary.

\section{Competing interests}

The authors declare that they have no competing interests.

\section{Authors' contributions}

All authors read and approved the final manuscript.

\section{Acknowledgement}

This work was supported from a grant the Agenda Program ((PJ007455), Rural Development Administration, Republic of Korea.

\section{Author details}

${ }^{1}$ Department of Occupational and Environmental Medicine, Hanyang University, Seoul, South Korea. ${ }^{2}$ Rural Development Administration, Seoul, South Korea.

Received: 19 December 2013 Accepted: 10 October 2014 Published online: 24 January 2015

\section{References}

1. Koh DK: A Study on Actual Condition of Farmer's Syndrome and Health Related Physical Fitness of Old People in a Rural Area of Kangwon. South Korea: Hallym University; 2001. Korean.

2. Park JS, Kwon SM, Oh YJ: Health promotion behavior, health problems, perceived health status and farmers' syndrome of rural residents. J Agri Med Commu Health 2009, 34(1):47-57. Korean.

3. Song JY: Farmers Syndrome And Their Related Factors Of Rural Residents In Chungnam Province. Chungnam National University; 1998. Korean.

4. Joo AR: A study on health promotion lifestyle, farmers' syndrome and related factors of workers in agricultural industry. Korean J Occup Health Nurs 2011, 21(1):37-45. Korean.

5. Statistics Korea http://kostat.go.kr/portal/korea/index.action

6. Walker SN, Sechrist KR, Pender NJ: The health-promoting lifestyle profile: Development and psychometric characteristics. Nurs Res 1987, 36(2):76-81.

7. Ware JE, Sherbournce CD: The MOS 36-item short-form health survey(SF-36): 1. Conceptual framework and item selection. Med Care 1992, 30(6):473-483.

8. Garratt AM, Hutchinson A, Russel I: Patient assessed measures of health outcome in asthma: a comparison of four approaches. Respir Med 2000, 94:597-606

9. Ware JE: Patient-based assessment: Tools for monitoring and improving healthcare outcomes. Behav Healthc Tomorrow 2001, 42(3):190-195.

10. Ware JE, Dewey JE: Health status and outcomes assessment tools. Int Electron J Health Educ 2000, 3:138-148.

11. Cha BS, Koh SB, Chang SJ, Park JK, Kang MG: The assessment of worker's health status by SF-36. Korean J occup Med 1998, 10(1):9-19. Korean.

12. Ware JE, Kosinski M, Keller SD: A 12-item short-form health survey: construction of scales and preliminary tests of reliability and validity. Med Care 1996, 34(3):220-233.

13. Song JS, Park WS, Choi HS, Seo JC, Kwak YH, Kim SA, Kim BS: Pesticide exposure of alpine agricultural workers in Gangwon-do and the measurement of their health status measured by SF-12. Korean J Pestic Sci 2005, 9(4):287-291. Korean.

14. Kim SA, Park KS, Jang MK, Kam S: Medical facilities utilization according to health status measured by SF-36 in male workers. Korean J occup Environ Med 2006, 18(4):272-283. Korean.

15. Lee SM: A Study on Employees' Health Status and Quality of Life By Using SF-12. Seoul, Korea: Catholic University; 2010. Korean.

16. Jun JY, Kim SA, Park WS, Oh MK, Hong YM: The assessment of rural elderly's health status by SF-36. Kwandong Med J 2001, 5(1):93-101. Korean.

17. Jenkinson C, Couler A, Wright L: Short form 36 (SF36) health survey questionnaire: normative data for adults of working age. BMJ 1993, 306:1437-1440. 
18. Ware JE: Measuring patients' views: the optimum outcome measure. BMJ 1993, 306:1429-1430.

19. Park KH: Factors Related to Self-Perceived Health of Young Adults. Seoul, South Korea: Yonsei University; 2000. Korean.

20. Nettleton S: The Sociology of Health and IIIness. Oxford: Polity Press; 1995

21. Maclntyre S: Gender differences in the perceptions of common cold system. Soc Sci Med 1993, 36:15-20.

22. Burdine JN, Felix MR, Abel AL, Wiltraut CJ, Musselman YJ: The SF-12 as a population health measure: an exploratory examination of potential for application. Health Serv Res 2000, 35(4):885-904.

23. Larson CO: Use of the SF-12 instrument for measuring the health of homeless persons. Health Serv Res 2002, 37(3):733-750.

24. Leigh JP, Schembri M: Instrumental variables technique: cigarette price provided better estimate of effects of smoking on SF-12. J Clin Epidemiol 2004, 57:284-293.

25. Jang IS: A study on self-rated health of elderly women in a rural community. J Korea Commun Health Nurs Acad Soc 2003, 17(1):35-46. Korean.

26. Lee KY, Park TJ: The association between social support and health status in the rural elderly. J Korean Acad Fam Med 2000, 21(5):672-682. Korean.

27. Wilson K, Rosenberg MW: Exploring the determinants of health for first nations people in Canada: can existing frameworks accommodate traditional activities? Soc Sci Med 2002, 55:2017-2031.

28. Song MS, Song HJ, Mok JY: Community based cross-sectional study on the related factors with perceived health status among the elderly. J Korea Geronto/ Soc 2003, 23(4):127-142. Korean.

29. Son DK, Lee KS, Park JK, Koh SB, Jin KN, Nam EW, Lee HS: Factors affecting health of the rural residents. Korean J of Health Policy Adm 2009, 19(4):1-17. Korean.

30. Lee SY, Son MS, Nam JM: Structural modeling of health concern, health practice and health status of Koreans. Korean J of Prev Med 1995, 28(1):187-205. Korean.

31. Ranford HE, Palis BJ: Aerobic exercise, subjective health and psychological well-being within age and gender subgroup. Soc Sci Med 1996, 42(11):1555-1559.

32. Pinqurt M: Correlates of subjective health in older adults. Psychol Aging 2001, 16(3):414-426.

33. Lee YH, Hong SC, Lee JY: The relationship between worker's health status and work ability index in small scale factories. Korean J Occup Environ Med 1998, 10(2):149-160. Korean.

34. Artazcoz L, Cortes L, Borrell C, Escriba-Aguir V: Gender perspective in the analysis of the relationship between long work hours, health and healthrelated behavior. Scand J Work Environ Health 2007, 33(5):344-350.

35. Heo HT, Kim DW, Lee JS, Jo HA, Jang SS, Kim SY, Kim IA: An association between working schedules and depression in public sector employees. Korean J Occup Environ Med 2012, 24(4):347-355.

36. Lalonde $\mathrm{M}$ : A new perspective on the health of canadians: A working document. Government of Canada 1981

\section{Submit your next manuscript to BioMed Central and take full advantage of:}

- Convenient online submission

- Thorough peer review

- No space constraints or color figure charges

- Immediate publication on acceptance

- Inclusion in PubMed, CAS, Scopus and Google Scholar

- Research which is freely available for redistribution

Submit your manuscript at www.biomedcentral.com/submit
Ciomed Central 